\title{
ACTIVE EVENT SPORT TOURISM EXPERIENCE: THE ROLE OF THE NATURAL ENVIRONMENT, SAFETY AND SECURITY IN EVENT BUSINESS MODELS
}

\author{
MARKO PERIĆ, JELENA ĐURKIN \& VANJA VITEZIĆ \\ University of Rijeka, Faculty of Tourism and Hospitality Management, Croatia
}

\begin{abstract}
The connection between tourism development and the natural environment is more intense in outdoor sport tourism than in many other forms of tourism. Natural settings (space), sport activities undertaken and the motivations of the people who participate in them interact to create sport tourism experiences. Tourist safety and security are also proved to be important elements of a tourist experience and it seems that sport tourists may be more sensitive to safety issues than non-sport tourists. This paper therefore aims to analyse the importance of the natural environment and safety and security issues, as constitute event business model elements, in providing sport tourism experiences. The natural setting is also examined as a motivation to participate in sport tourism travel. On the basis of 464 questionnaires gathered from active participants of 16 small-scale sport events in four different outdoor sports, exploratory factor analysis was conducted on motivational statements and revealed a conceptually clear sevenfactor structure. One of them, titled 'Nature', was the second most important motivational dimension for participants but differences between particular sports were considerable. In terms of business model elements included in the survey, participants gave high importance to all elements related to the natural environment and safety and security. Scenic destination, scenic and interesting course, course safety and event safety were the most important elements of event business models for participants in all four sports. Environmental management and proper implementation of security and crowd control measures were also singled out as important event processes. However, results of ANOVA indicate statistically significant differences between the sports in seven out of nine business model elements. These findings shed some light on the managerial aspects of sport tourism practice, helping managers to better serve sports and tourism needs at a particular event and in the destination.
\end{abstract}

Keywords: business model, event sport tourism, natural environment, safety and security.

\section{INTRODUCTION}

Sport tourism is a complex phenomenon that is not only a simple sum of sport and tourism. Both similar and different from sport and tourism individually, sport tourism is multi-faceted and exists under a variety of forms and names [1-4]. Participants travel to take part in sport, to watch sport, and to visit sports-related attractions. Depending on different participation (active or passive) and motivation factors, sport tourists encounter various experiences as the ultimate value they are seeking $[5,6]$.

The sport tourism experience is indeed a complex (and) individual construct involving motivational, emotional, social, environmental, organisational and physical attributes [7-9]. According to Weed and Bull [4], three key components interact to create value (i.e. the experience) in sport tourism, namely the places involved, the activities undertaken and the motivations of the people who participate. The places that host tourists and their activities have some distinct characteristics (e.g. attractive landscapes, beautiful sceneries etc.) which are a subject of different interpretations [9-11]. On the other hand, the number of tourists and their activities could cause destruction of physical, economic or sociocultural means and reduce the quality of the satisfaction of tourists. For this reason, defining and respecting the carrying capacity of destinations becomes an imperative in tourism planning $[12,13]$. In addition, safety and security are important elements of the tourist experience [14] and it 
seems personal safety is more highly valued by sport tourists than by non-sport tourists $[15$, 16]. In sport tourism literature, many of these organisational, environmental and other attributes are analysed within the context of event and destination preferences [17, 18]. However, when it comes to business models which provide a description of how value (i.e. the sport tourism experience) is produced and delivered, and what value remains within, and for, an organisation, some components like the natural environment and safety and security have been significantly neglected [6].

This paper therefore aims to analyse the importance of the natural environment and safety and security issues, as constitute event business model elements, in providing sport tourism experiences. The natural setting is also examined as a motivation to participate in sport tourism travel. The fact that these issues were usually disregarded in previous research concerning business models makes this research innovative.

The paper starts with a short literature review examining a range of perspectives regarding the natural environment and safety and security in sport tourism and within a business model framework. The second section provides a description of the research method. The third section exposes and discusses the results. The final section offers discussion and concluding remarks, highlighting some further theoretical and managerial implications.

\section{LITERATURE REVIEW}

\subsection{Natural environment and sport tourism}

The connection between tourism development and extraordinary environments is even more intense in sport tourism than in many other forms of tourism [19, 20]. Whatever the sport tourism activity, it takes place in an interactive area which can be natural or artificial (created by people). What is more, the natural environment is a key resource when it comes to outdoor sport tourism that is much more dependent on natural environmental conditions [21-24].

For this reason, environmental aspects such as beautiful scenery or countryside are widely recognised as factors that strongly influence the sport tourism experience and customer satisfaction $[8,9,25,26]$. Some environmental aspects like scenic course, scenic destination and expected weather conditions are often studied when preferences on sporting events and destinations are analysed $[17,18]$. What's more, different types of tourists perceive landscape values differently $[10,11,27]$. Since these values are fragile, both consumers and providers must be aware of the environmental carrying capacity $[12,13,28]$ and increase their efforts in preventing the negative impacts of tourism on soil, water resources, vegetation and animal life as well as on economic and sociocultural aspects of life. This will largely depend on their attitude on environment, that is, environmental value orientation which strongly determines the behaviour $[20,29,30]$.

Another perspective discusses natural environments as a motivation to travel and to participate in sports, and various researchers highlight that landscapes and natural settings are indeed important sport travel motivators [31-34] and that nature has a strong influence on the tourist perception of a chosen destination $[11,19]$. In other words, nature itself and the wish to experience nature are strong motivations to participate in outdoor sport tourism events. Event sport tourism has developed as the highest profile product within sports tourism [35]. In previous research, however, the focus has mostly been on mega events and/or whole destinations, while small-scale sport events have been insufficiently studied. Additionally, by calculating mean scores or performing factor analysis when segmenting sport tourists, many authors have found 
that enjoying nature and experiencing nature and the environment are important dimensions when taking sport tourism trips (e.g. [36-38]). It can be presumed that the same motivations exist in different sports, and the desire to experience nature is one of them.

\subsection{Safety and security and sport tourism}

The frequency and severity of natural and environmental threats and human-induced incidents has dramatically increased in the 21 st century. Studies indicate that tourist safety and security are proved to be important elements of a tourist experience [1] and an absolute prerequisite for a successful tourist operation [39-41]. As the most important decision-making aspects for a significant number of tourists [42], the risk perceptions of travellers concerning their personal safety are deemed as being influential on international tourism demand patterns. Consequently, unsafe destinations will have difficulties in attracting tourists [40, 43]. Tourism development will slow down for a shorter or longer time, depending on the response of all stakeholders involved in the tourism industry.

Sport tourism has additional features where safety and security are concerned. Since active participation in sports increases the possibility of injury, it seems that sport tourism implies a higher level of risks compared to other specific types of tourism. In this regard, course safety was proved to be an important attribute for active sport event tourists [18]. Additionally, many sporting events take place outdoors where safety is more difficult to ensure. The safety theme is also recognised as crucial in the context of sport facilities and spectator sports [44, 45], as well as active sport tourists $[18,46]$. Therefore, it is argued that sport tourists (both active and passive) may be more sensitive to safety issues related to a destination and an event $[15,16,47]$ in comparison with non-sport tourists. From the perspective of tourism supply, sport tourism providers need to minimize safety risks thus supporting the functional value of the experience [48]. Safety concerns (e.g. safer routes) are imbedded in the event organisation and organisational aspect of the experience which is under the control of the provider [8, 46].

\subsection{Environment and safety and security within a business model framework}

Despite some disagreements in definitions of the term business model and its basic elements, the majority of researchers agree that a business model is all about value - how value is created and delivered to the customer and how value is captured by the organisation itself [49-51].

Literature on business models in tourism mostly refers to e-tourism business models and travel agencies (e.g. [52-56]). This is understandable considering the significant influence that the Internet has had over the past 20 years, but it is certainly surprising given the importance that the tourism industry has in the world's economy. When it comes to sport tourism, Peric and Wise [57] used the business model framework of Johnson et al. [58] and compared the business models of two hospitality firms in sport (tennis) tourism. Recently, Perić et al. [6] proposed an innovative business model for sustainable sport tourism, consisting of 27 different elements, grouped within four broader clusters (value proposition, key resources, key processes and value capture). It seems the analytical possibilities of a business model framework have not been recognised by tourism researchers [59]. This applies to sport tourism as well, where a new service research agenda is proposed, to try fill the void that would link the concept of business models to the area of sport tourism management [60]. 
In the last few decades, the competitive landscape has changed in favour of the environment and firms started to treat sustainability as a business strategy in itself. However, despite the fact that Sustainability Business Models (SBMs) [61, 62] acknowledged environment and community as true stakeholders and therefore devoted its interest to the social and environmental dimensions of sustainability as well, the environment is rarely considered as an element of a business model. For instance, Perić et al. [6] studied 102 publications on business models and found that environment is considered a business model element only twice (see $[63,64]$ ). However, when mentioned in the context of business models, the environment has a meaning of a turbulent and competitive business setting that impacts firms' survival and does not refer to a nature setting. As the natural environment is considered a key resource for sport tourism providers, especially when it comes to outdoor activities, efforts aimed at protecting the environment and its carrying capacity should be viewed as another key process. On the other hand, Perić et al. [6] found no results for safety and security but after in-depth analysis, they proposed that safety should be part of the customer value proposition (like experience), whereas security, as an organizational issue, should belong to key processes.

\section{METHOD}

A self-administered questionnaire (available at: https://www.1ka.si/a/100714) was used to analyse the importance of the natural environment, safety and security from the perspective of active sport event participants. The questionnaire was developed within the project SPORTBIZMODEL and contained eight parts altogether, only three of which are the focus of this study: motivation; business model elements with focus on environmental and safety and security issues; and socio-economic and demographic data (age, gender, education, income). Items measuring motivation for sport participation (28 in total) were selected from the Physical Activity and Leisure Motivation Scale (PALMS), originally developed by Morris and Rogers [65], and expanded with four items regarding natural settings [8, 31, 34] and items regarding charity and prizes $[17,18]$. The section investigating the importance of the natural environment (four items) and safety and security issues (five items) as parts of the business model was constructed based on previous research on event and destination preferences [17, 18] and business models in sport tourism [6]. Participants answered the questionnaire on a 5-point Likert scale, ranging from 1-Strongly disagree to 5-Strongly agree (for motivational items) and 1-Not important at all to 5-The most important (for business model items). The questionnaire was prepared in printed and online versions in four languages (Croatian, Slovenian, English and Italian).

A survey was conducted from July 2016 to April 2017 in Croatia and Slovenia. Respondents were active participants of 16 small-scale sport events in four different outdoor sports (see Table 1): trail running (three events), sport fishing (four events), mountain biking (seven events), and cross-country skiing (two events). The 464 questionnaires collected were acceptable for this study. Descriptive analysis was applied to explore the sample profile of the study. Exploratory factor analysis (EFA) using the extraction method Principal Axis Factoring with direct oblimin rotation was used to reduce the 28 motivations to a smaller number of factors. Participants were then grouped based on particular sports, and the groups' mean responses in relation to the motivational factors and business model elements related to the natural environment and safety and security were examined. ANOVA was used to identify possible statistically significant differences between the groups in terms of the factors derived from the EFA and proposed business model elements. 
Table 1: Events' portfolio in chronological order.

\begin{tabular}{|c|c|c|c|c|}
\hline Events & Sport & Date & Place & No. of part. \\
\hline Risnjak Trail & TR & 9 July 2016 & $\begin{array}{l}\text { Crni Lug, National } \\
\text { Park Risnjak, Croatia }\end{array}$ & 399 \\
\hline $\begin{array}{l}\text { Gorski kotar Bike Tour } \\
2016\end{array}$ & MTB & 15-17 July 2016 & Gorski kotar, Croatia & 30 \\
\hline Black Hole Marathon & MTB & 23 July 2016 & $\begin{array}{l}\text { Črna na Koroškem, } \\
\text { Slovenia }\end{array}$ & 145 \\
\hline $\begin{array}{l}\text { Kamenjak Mountain Bike } \\
\text { Tour }\end{array}$ & МTB & 5-7 August 2016 & $\begin{array}{l}\text { Tršće, Gorski kotar, } \\
\text { Croatia }\end{array}$ & 26 \\
\hline Rekreatur 2016 & MTB & $\begin{array}{l}25-28 \text { August } \\
2016\end{array}$ & $\begin{array}{l}\text { Savinja and Šalek Val- } \\
\text { ley, Kranj, Slovenia }\end{array}$ & 100 \\
\hline Fužine2Sea & МТB & 28 August 2016 & $\begin{array}{l}\text { Fužine - Crikvenica, } \\
\text { Croatia }\end{array}$ & 248 \\
\hline 38th Assault on Vršič & MTB & $\begin{array}{l}3 \text { September } \\
2016\end{array}$ & $\begin{array}{l}\text { Kranjska Gora, Slove- } \\
\text { nia }\end{array}$ & 672 \\
\hline Ogulin Trail 2016 & TR & $\begin{array}{l}\text { 17 September } \\
2016\end{array}$ & Ogulin, Croatia & 178 \\
\hline 3rd Sakura UL Cup & $\mathrm{SF}$ & $\begin{array}{l}\text { 18 September } \\
2016\end{array}$ & $\begin{array}{l}\text { Mrzla vodica, Lokve, } \\
\text { Croatia }\end{array}$ & 40 \\
\hline Dalmacija Ultra Trail & TR & $\begin{array}{l}21-23 \text { October } \\
2016\end{array}$ & Omiš, Croatia & 349 \\
\hline Pike Masters II & $\mathrm{SF}$ & 29 October 2016 & Orešje, Zagreb, Croatia & 40 (20 teams) \\
\hline $\begin{array}{l}\text { 3rd Prologic "Carp Chal- } \\
\text { lenge Mrežnica 2016" }\end{array}$ & SF & $\begin{array}{l}\text { 25-27 Novem- } \\
\text { ber } 2016\end{array}$ & Duga Resa, Croatia & 20 (10 teams) \\
\hline Marathon Tamar & CCS & 18 January 2017 & Rateče, Slovenia & 36 \\
\hline Pokljuka Marathon AS & $\mathrm{CCS}$ & 4 March 2017 & Pokljuka, Slovenia & 78 \\
\hline Downhill Lošinj 2017 & МТB & 22 April 2017 & Veli Lošinj, Croatia & 121 \\
\hline Golden Trout 2017 & $\mathrm{SF}$ & 23 April 2017 & Čabar, Croatia & 42 \\
\hline
\end{tabular}

Note: TR - Trail running; MTB - Mountain biking; SF - Sport fishing; CCS - Cross-country skiing

\section{RESULTS}

The respondents profile for each sporting activity is presented in Table 2. Descriptive analysis showed that the events are male dominated, with sport fishing being a completely male sporting activity. Mountain bike and cross-country skiing participants are slightly older when compared with trail and sport fishing participants and in most cases they are married and have children. The majority of trail running and mountain bike participants have university or higher degrees, while sport fishing participants usually have secondary school qualifications. Most of the respondents have a monthly net income between 500 and 1,500 euro.

EFA was performed on the motivation scale. The Kaiser-Meyer-Olkin (KMO) measure of sampling adequacy $(0.844)$ and the Bartlett's test of sphericity $(\mathrm{p}<0.001)$ confirmed that the 
Table 2: Sample profile.

\begin{tabular}{|c|c|c|c|c|c|c|c|c|}
\hline \multirow[b]{2}{*}{ Variable } & \multicolumn{2}{|c|}{$\mathrm{TR}(\mathrm{N}=140)$} & \multicolumn{2}{|c|}{$\mathrm{SF}(\mathrm{N}=89)$} & \multicolumn{2}{|c|}{$\operatorname{MTB}(\mathrm{N}=183)$} & \multicolumn{2}{|c|}{$\operatorname{CCS}(\mathrm{N}=52)$} \\
\hline & Freq. & $\%$ & Freq. & $\%$ & Freq. & $\%$ & Freq. & $\%$ \\
\hline GENDER & $\mathrm{N}=139$ & & $\mathrm{~N}=88$ & & $\mathrm{~N}=176$ & & $\mathrm{~N}=51$ & \\
\hline M & 89 & 64.0 & 88 & 100.0 & 118 & 67.0 & 37 & 72.5 \\
\hline $\mathrm{F}$ & 50 & 36.0 & 0 & 0.0 & 58 & 33.0 & 14 & 27.5 \\
\hline MARITAL STATUS & $\mathrm{N}=139$ & & $\mathrm{~N}=86$ & & $\mathrm{~N}=175$ & & $\mathrm{~N}=50$ & \\
\hline Single & 70 & 50.4 & 37 & 43.0 & 89 & 50.9 & 22 & 44.0 \\
\hline Married & 69 & 49.6 & 49 & 57.0 & 86 & 49.1 & 28 & 56.0 \\
\hline HAVING CHILDREN & $\mathrm{N}=135$ & & $\mathrm{~N}=87$ & & $\mathrm{~N}=176$ & & $\mathrm{~N}=50$ & \\
\hline No & 73 & 54.1 & 33 & 37.9 & 89 & 50.6 & 19 & 38.0 \\
\hline Yes & 62 & 45.9 & 54 & 62.1 & 87 & 49.4 & 31 & 62.0 \\
\hline EDUCATION & $\mathrm{N}=138$ & & $\mathrm{~N}=88$ & & $\mathrm{~N}=174$ & & $\mathrm{~N}=51$ & \\
\hline No education & 1 & 0.7 & 0 & 0.0 & 0 & 0.0 & 0 & 0.0 \\
\hline Elementary & 0 & 0.0 & 1 & 1.1 & 6 & 3.4 & 0 & 0.0 \\
\hline Secondary & 28 & 20.3 & 65 & 73.9 & 65 & 37.4 & 27 & 52.9 \\
\hline University & 90 & 65.2 & 19 & 21.6 & 84 & 48.3 & 20 & 39.2 \\
\hline Postgraduate & 19 & 13.8 & 3 & 3.4 & 19 & 10.9 & 4 & 7.8 \\
\hline MONTHLY NET INCOME & $\mathrm{N}=132$ & & $\mathrm{~N}=84$ & & $\mathrm{~N}=164$ & & $\mathrm{~N}=48$ & \\
\hline 0-500 EUR & 13 & 9.7 & 12 & 14.3 & 27 & 16.5 & 13 & 27.1 \\
\hline 500-1000 EUR & 53 & 39.6 & 44 & 52.4 & 69 & 42.1 & 16 & 33.3 \\
\hline 1000-1500 EUR & 33 & 24.6 & 21 & 25.0 & 42 & 25.6 & 10 & 20.8 \\
\hline 1500-2000 EUR & 21 & 15.7 & 3 & 3.6 & 17 & 10.4 & 5 & 10.4 \\
\hline 2000-3000 EUR & 6 & 4.5 & 2 & 2.4 & 6 & 3.7 & 4 & 8.3 \\
\hline $3000-4000$ & 5 & 3.7 & 1 & 1.2 & 1 & 0.6 & 0 & 0.0 \\
\hline$>4000$ EUR & 3 & 2.2 & 1 & 1.2 & 2 & 1.2 & 0 & 0.0 \\
\hline AGE & $\mathrm{N}=128$ & & $\mathrm{~N}=86$ & & $\mathrm{~N}=173$ & & $\mathrm{~N}=51$ & \\
\hline Average age & & 37.8 & & 40.4 & & 37.5 & & 38.3 \\
\hline
\end{tabular}

Note: TR - Trail running; MTB - Mountain biking; SF - Sport fishing; CCS - Crosscountry skiing

analysis was appropriate for the collected responses. Four items were dropped ('To raise money for charity', 'To get away from pressures of everyday life', 'To better cope with stress' and 'To help me relax') because their factor loadings were below 0.3 for all factors. The analysis revealed a conceptually clear factor structure (Table 3). Seven factors with eigenvalues greater than 1 emerged (1-Nature, 2-Appearance, 3-Competition, 4-Socializing, 5-Enjoyment, 6-Skills, and 7-Health), which accounted for $74.47 \%$ of the variance. The first factor, called 'Nature', explained $24.897 \%$ of variance and consists of four items, all associated with natural environment ('Because I want to connect with nature', 'Because I seek an 
Table 3: Results of the exploratory factor analysis.

\begin{tabular}{|c|c|c|c|c|c|c|c|}
\hline \multirow{2}{*}{$\begin{array}{l}\text { Statement } \\
\text { I undertake this particular sport activity... }\end{array}$} & \multicolumn{7}{|l|}{ Factor } \\
\hline & 1 & 2 & 3 & 4 & 5 & 6 & 7 \\
\hline Because I want to connect with nature & .798 & & & & & & \\
\hline $\begin{array}{l}\text { Because I seek an unpolluted environ- } \\
\text { ment (clean air and/or water) }\end{array}$ & .783 & & & & & -.138 & \\
\hline To enjoy beautiful surroundings & .733 & & & & & & \\
\hline Because I want to be in nature (outdoors) & 619 & & & & .264 & .148 & \\
\hline To improve my appearance & & .919 & & & & & \\
\hline To improve my body shape & & .885 & & & & & \\
\hline To maintain a trim, toned body & & .737 & & & & & .125 \\
\hline To be the best in a group & & & .874 & & & & \\
\hline To compete with others around me & & & .757 & & & & \\
\hline To be fitter than others & & & .729 & & & & \\
\hline For the prize(s) & & & .674 & & & -.133 & -.115 \\
\hline To enjoy spending time with others & & & & -.833 & & & \\
\hline To do the activity with others & & & & -.818 & & & \\
\hline To be with friends & & & & -.802 & & & \\
\hline Because it makes me happy & & & & & .863 & & \\
\hline Because it is fun & & & & & .847 & & \\
\hline Because it is interesting & & & & & .658 & -.217 & \\
\hline Because I enjoy doing this sport & .198 & -.100 & .137 & & .615 & & \\
\hline To obtain new skills & & & & & & -.822 & \\
\hline To improve existing skills & & & & & & -.742 & \\
\hline To maintain a current skill level & & & & & & -.415 & .118 \\
\hline To maintain my health & & & & & & & .885 \\
\hline To improve cardiovascular fitness & & & & & & & .726 \\
\hline To be physically fit & & .134 & & & & & .633 \\
\hline$\%$ of variance & 24.897 & 16.417 & 79.989 & 8.117 & 5.422 & 5.321 & 4.309 \\
\hline
\end{tabular}

Note: Extraction Method: Principal Axis Factoring. Rotation Method: Oblimin with Kaiser Normalisation. $^{\mathrm{a}}$

${ }^{a}$ Rotation converged in 7 iterations.

unpolluted environment', 'To enjoy beautiful surroundings', and 'Because I want to be in nature').

When it comes to the mean values of responses regarding items within factors, those related to 'Enjoyment' and 'Nature' have the highest level of agreement, above 4.50 (Table 4). There are statistically significant differences in mean values among the sports in six out of seven motivational factors. Regarding the groups' mean responses in relation to nine business model items related to the natural environment and safety and security, participants from all four sports rated highly all nine of them (from 3.76 to 4.34) (Table 4). 'Scenic destination' 
Table 4: Mean values and ANOVA results of motivational factors and business model elements.

\begin{tabular}{lrrrrrr}
\hline & TR & SF & MTB & CCS & F & Sig. \\
\hline Motivational factors (overall mean) & & & & & & \\
Nature (4.51) & 4.57 & 4.71 & 4.39 & 4.42 & 8.017 & .000 \\
Appearance (3.17) & 3.22 & 2.57 & 3.35 & 3.44 & 12.718 & .000 \\
Competition (3.00) & 2.67 & 3.52 & 2.99 & 3.03 & 13.915 & .000 \\
Socializing (4.32) & 4.27 & 4.43 & 4.41 & 3.93 & 7.927 & .000 \\
Enjoyment (4.59) & 4.67 & 4.68 & 4.53 & 4.36 & 7.628 & .000 \\
Skills (4.04) & 3.98 & 4.19 & 4.03 & 3.99 & 1.782 & .150 \\
Health (4.24) & 4.38 & 3.75 & 4.32 & 4.47 & 21.086 & .000 \\
Business model - related items (overall mean) & & & & & & \\
A scenic and interesting course (4.26) & 4.46 & 3.99 & 4.28 & 4.10 & 7.720 & .000 \\
The destination is scenic (4.34) & 4.36 & 4.28 & 4.36 & 4.31 & .345 & .793 \\
The expected weather conditions are & 3.51 & 3.84 & 3.95 & 3.61 & 5.817 & .001 \\
favourable (3.76) & & & & & & \\
Proper implementation of environmental & 4.24 & 4.29 & 4.09 & 3.94 & 2.867 & .036 \\
protection measures (4.16) & & & & & & \\
Course safety (4.17) & 4.08 & 3.97 & 4.27 & 4.38 & 4.556 & .004 \\
Event safety (4.16) & 4.14 & 3.93 & 4.26 & 4.28 & 3.809 & .010 \\
The destination is a safe place to stay and visit & 4.07 & 4.24 & 4.22 & 4.33 & 1.795 & .147 \\
(4.19) & & & & & & \\
$\begin{array}{l}\text { Proper implementation of security measures } \\
\text { (3.98) }\end{array}$ & 3.89 & 3.84 & 4.10 & 4.08 & 2.862 & .037 \\
Proper implementation of crowd control & 3.99 & 3.65 & 3.92 & 4.08 & 3.759 & .011 \\
measures (3.91) & & & & & & \\
\hline No: TR - Tral & & & & & & \\
\hline
\end{tabular}

Note: TR - Trail running; MTB - Mountain biking; SF - Sport fishing; CCS - Cross-country skiing

was the most important for the whole sample, with no statistically significant differences between sports. However, there are statistically significant differences in seven out of nine items regarding the average importance among the sports. 'Scenic and interesting course', 'course safety' and 'event safety' were other important elements for participants in all four sports. 'Favourable weather conditions' was the least important item for the participants in all four sports but differences between them were considerable.

\section{DISCUSSION AND CONCLUSION}

Given the spatial (places), physical (activities) and social (people) aspects of sport tourism experiences $[4,21]$, this paper seeks to examine the role of the natural environment and safety and security in providing this particular value within the setting of small-scale outdoor sporting events belonging to four different sports (trail running, sport fishing, mountain biking and cross-country skiing). 
Regarding motivations (i.e. the people perspective), seven factors emerged, and mean scores suggest 'Nature' is among the top three most important dimensions in all four sports. People do indeed participate in outdoor sports to experience and merge with nature. Socializing, health issues and skills mastery are less important motivations. These results support prior research (e.g. $[11,31,34,37,38]$ ), noting that the dimension of experiencing nature is relevant to both recreational and tourism contexts as a strong motivation for taking sport (and) tourism trips. As an important motivation, it strongly contributes to the overall sport tourism experience, as claimed by Bouchet et al. [21], Klaus and Maklan [9] and Perić et al. [60] and, therefore, allows for finer profiling of the value proposition within a business model framework. However, the importance of the 'Nature' factor differs significantly depending on the sport. It is interesting to note that 'Nature' is more important for sport fishing participants than it is for the participants in the other three sports. Based on this discussion, the natural environment was confirmed as a strong motivation for participating in outdoor sporting events.

The natural environment, along with safety and security issues, was further discussed regarding the importance these features have for a sport tourism business model. Active sport event participants gave high importance to all elements related to the natural environment and safety and security. When it comes to the natural setting, it is not only about the course (the natural environment in a narrow sense) but also about the destination as a whole. This study's findings are in line with Getz and McConnell [17] and Buning and Gibson [18] who also found that a scenic course and destination are important sporting event and destination attributes. The lesser importance of 'expected weather conditions' can be explained by the fact that competitions in these sports are not cancelled in case of bad weather conditions and that competitors in these sports get used to them. However, when evaluating the environmental features some statistically significant differences between sports exist implying that the perception and valuation of the same features could differ depending on types of tourists (see [10]). It turns out that the tourists' valuation of landscapes should therefore be taken into consideration when developing recreational activities associated with tourism [27]. Further, active sport event participants want to see event organisers doing everything they can to keep their business models' core resource, that is, the natural environment (both course and destination), clean and protected from environmental risks. Using the latest and safest equipment and technology, event organisers can contribute to environmental protection and the sustainable use of natural resources, thus supporting the destination's carrying capacity [12, 13, 21]. Undoubtedly, environmental management should therefore be an important process within tourism enterprise business models [6, 59].

Findings further confirm previous conclusions on how important safety and security issues are for tourism experiences $[14,16,18,26]$. Course, event and destination safety are indeed the key elements appraised by active sport event attendees, thus contributing to the overall value the event participants receive (i.e. these key elements belong to the customer value proposition). In addition, the proper implementation of security and crowd control measures is of high importance for active sport event participants and should, therefore, be one of the key processes within the event's business model as claimed by Perić et al. [6]. However, since the mean values are lower, it seems safety issues are less important than natural settings attributes (except for weather conditions). Some differences between sports exist, and the reason sport fishing participants gave less importance to safety and security issues might lie in the small-scaled nature (up to 45 participants per event) and intimate atmosphere of examined sport events. 
To summarise, sport in general is the common theme for all respondents included in the sample, but other factors are also decisive in creating active sport event experiences. The high mean scores of the 'Nature' dimension (as a motivation to participate) and of the natural environment and safety as business model elements, given by the active event participants, show the importance of respecting the physical environment and safety in the examined sports. From a conceptual viewpoint, these findings shed some light on the managerial aspects of sport tourism practice. The results of this study can be used by the small, private-owned businesses, predominant in the event sport tourism economy, to refocus and innovate their business models and implement more effective strategies. These results should also be taken into consideration when sport resorts in general and sporting events in particular are planned and built. Such efforts will help sport tourism providers to better serve sports and tourism needs at a particular event and in the destination but also to preserve the destination from negative impacts caused by tourists' activities. Failure to do so could impact future attendance, as well as word-of-mouth about the event.

Despite our attempts to rigorously and objectively analyse the selected literature on safety and environmental issues in the context of sport tourism and business models, this paper comes with several limitations. First, our sample was derived from manifold sporting events. Focus on only one sport, or the introduction of new sports, could deliver different results. The same would apply if the focus were on large-scale sporting events. Second, in line with Gangaas et al. [29], it would be interesting to examine whether the participants' motivations and preferences on particular business model elements depend on their environmental value orientation. Also, event sport tourism industry has other features that should be explored within a business model context and their interaction/relation to nature, safety and security elements (e.g. transport), examined. Future research on business models in the sport tourism industry should seek to overcome these limitations.

\section{ACKNOWLEDGEMENTS}

This work has been supported in part by the Croatian Science Foundation under the project UIP-2014-09-1214.

\section{REFERENCES}

[1] Gammon, S. \& Robinson, T., Sport and tourism: a conceptual framework. Journal of Sport Tourism, 4(3), pp. 11-18, 1997. https://doi.org/10.1080/10295399708718632

[2] Gibson, H., Sport tourism: a critical analysis of research. Sport Management Review, 1(1), pp. 45-76, 1998. https://doi.org/10.1016/S1441-3523(98)70099-3

[3] Glyptis, S., Sport and Tourism in Western Europe, British Travel Education Trust, London, 1982.

[4] Weed, M. \& Bull, C., Sport Tourism: Participants, policy and providers, Elsevier Butterworth Heinemann, Oxford, 2009.

[5] Prahalad, C.K. \& Ramaswamy, V., Co-creation experiences: The next practice in value creation. Journal of Interactive Marketing, 18(3), pp. 5-14, 2004. https://doi.org/10.1002/dir.20015 
[6] Perić, M., Vitezić, V. \& Mekinc, J., Conceptualising innovative business models for sustainable sport tourism. International Journal of Sustainable Development and Planning, 11(3), pp. 469-482, 2016.

https://doi.org/10.2495/SDP-V11-N3-469-482

[7] Morgan, M., Elbe, J. \& Curiel, J.E., Has the experience economy arrived? the views of destination managers in three visitor-dependent areas. International Journal of Tourism Research, 11(2), pp. 201-216, 2009. https://doi.org/10.1002/jtr.719

[8] Kaplanidou, K. \& Vogt, C., The meaning and measurement of a sport event experience among active sport tourists. Journal of Sport Management, 24(5), pp. 544-566, 2010. https://doi.org/10.1123/jsm.24.5.544

[9] Klaus, P. \& Maklan, S., Bridging the gap for destination extreme sports - a model of sports tourism customer experience. Journal of Marketing Management, 27(13-14), pp. 1341-1365, 2011. https://doi.org/10.1080/0267257X.2011.624534

[10] Scolozzi, R., Schirpke, U., Detassis, C., Abdullah, S. \& Gretter, A., Mapping alpine landscape values and related threats as perceived by tourists. Landscape Research, 40(4), pp. 451-465, 2015. https://doi.org/10.1080/01426397.2014.902921

[11] Bastian, O., Stein, C., Lupp, G., Behrens, J., Renner, C. \& Grunewald, K., The appreciation of nature and landscape by tourism service providers and visitors in the Ore Mountains (Germany). Landscape Online, 41, 1-23, 2015. https://doi.org/10.3097/LO.201541

[12] Shi, L., Zhao, H., Li, Y., Ma, H., Yang, S. \& Wang, H., Evaluation of Shangri-La County's tourism resources and ecotourism carrying capacity. International Journal of Sustainable Development \& World Ecology, 22(2), pp. 103-109, 2015. https://doi.org/10.1080/13504509.2014.927018

[13] Navaro Jurado, E. et al. Carrying capacity assessment for tourist destinations. Methodology for the creation of synthetic indicators applied in a coastal area. Tourism Management, 33(6), pp. 1337-1346, 2012. https://doi.org/10.1016/j.tourman.2011.12.017

[14] Otto, J.E. \& Ritchie, J.R.B., The service experience in tourism. Tourism Management, 17(3), pp. 165-174, 1996. https://doi.org/10.1016/0261-5177(96)00003-9

[15] Mohan, L.J., Effect of destination image on attendance at sporting events. Tourism and Hospitality Research, 10(3), pp. 157-170, 2010. https://doi.org/10.1057/thr.2010.1

[16] Chen, N. \& Funk, D.C., Exploring destination image, experience and revisit intention: a comparison of sport and non-sport tourist perceptions. Journal of Sport \& Tourism, 15(3), pp. 239-259, 2010. https://doi.org/10.1080/14775085.2010.513148

[17] Getz, D. \& McConnell, A., Serious sport tourism and event travel careers. Journal of Sport Management, 25(4), pp. 326-338, 2011. https://doi.org/10.1123/jsm.25.4.326 
[18] Buning R.J. \& Gibson H, Exploring the trajectory of active sport event travel careers: a social worlds perspective. Journal of Sport Management, 30(3), pp. 265-281, 2016. https://doi.org/10.1123/jsm.2015-0213

[19] Hinch, T. \& Higham, J., Sport Tourism Development, Channel View Publications, Clevedon, 2004.

[20] Han, J.H., Nelson, C.M. \& Kim, C., Proenvironmental behavior in sport event tourism: roles of event attendees and destinations. Tourism Geographies, 17(5), pp. 719-737, 2015.

https://doi.org/10.1080/14616688.2015.1084037

[21] Bouchet, P., Lebrun, A.M. \& Auvergne, S., Sport tourism consumer experiences: a comprehensive model. Journal of Sport \& Tourism, 9(2), pp. 127-140, 2004. https://doi.org/10.1080/14775080410001732578

[22] IOC Guide to Sport, Environment and Sustainable Development, 6 2006; International Olympic Committee. Available at www.olympic.org/assets/importednews/documents/ en_report_1112.pdf (accessed 11 October 2015).

[23] MacIntosh, E., Apostolis, N. \& Walker, M., Environmental responsibility: internal motives and customer expectations of a winter sport provider. Journal of Sport \& Tourism, 18(2), pp. 99-116, 2013. https://doi.org/10.1080/14775085.2013.838145

[24] Trendafilova, S., Babiak, K. \& Heinze, K., Corporate social responsibility and environmental sustainability: why professional sport is greening the playing field. Sport Management Review, 16(3), pp. 298-313, 2013. https://doi.org/10.1016/j.smr.2012.12.006

[25] Högström, C., Rosner, M. \& Gustafsson, A., How to create attractive and unique customer experiences; an application of Kano's theory of attractive quality to recreational tourism. Marketing Intelligence \& Planning, 28(4), pp. 385-402, 2010. https://doi.org/10.1108/02634501011053531

[26] Hallmann, K., Feiler, S., Müller, S. \& Breuer, C., The interrelationship between sport activities and the perceived winter sport experience. Journal of Sport \& Tourism, 17(2), pp. 145-163, 2012. https://doi.org/10.1080/14775085.2012.729905

[27] Schmitz, M.F., de Aranzabal, I. \& Pineda, F.D., Spatial analysis of visitor preferences in the outdoor recreational niche of Mediterranean cultural landscapes. Environmental Conservation, 34(04), pp. 300-312, 2007. https://doi.org/10.1017/S0376892907004249

[28] Zhang, Y., Li, W.R. \& Su, Q., Does spatial layout matter to theme park tourism carrying capacity? Tourism Management, 61, pp. 82-95, 2017. https://doi.org/10.1016/j.tourman.2017.01.020

[29] Gangaas, K.E., Kaltenborn, B.P. \& Andreassen, H.P., Environmental attitudes associated with large-scale cultural differences, not local environmental conflicts. Environmental Conservation, 42(1), pp. 41-50, 2015. https://doi.org/10.1017/S0376892914000125

[30] Xu, F. \& Fox, D., Modelling attitudes to nature, tourism and sustainable development in national parks: a survey of visitors in China and the UK. Tourism Management, 45, pp. 142-158, 2014. https://doi.org/10.1016/j.tourman.2014.03.005 
[31] Kulczycki, C. \& Halpenny, E.A., Sport cycling tourists' setting preferences, appraisals and attachments. Journal of Sport \& Tourism, 19(2), pp. 169-197, 2014. https://doi.org/10.1080/14775085.2015.1070741

[32] Moore, R., Richardson, M. \& Corkill, C., Identity in the "road racing capital of the world": heritage, geography and contested spaces. Journal of Heritage Tourism, 9(3), pp. 228-245, 2014. https://doi.org/10.1080/1743873X.2014.904318

[33] Aicher, T.J. \& Brenner, J., Individuals' motivation to participate in sport tourism: a self-determination theory perspective. International Journal of Sport Management Recreation \& Tourism, 18(d), pp. 56-81, 2015. https://doi.org/10.5199/ijsmart-1791-874X-18d

[34] Pomfret, G. \& Bramwell, B., The characteristics and motivational decisions of outdoor adventure tourists: a review and analysis. Current Issues in Tourism, 19(14), pp. 1447-1478, 2016. https://doi.org/10.1080/13683500.2014.925430

[35] Weed, M., Progress in sports tourism research? a meta-review and exploration of futures. Tourism Management, 30(5), pp. 615-628, 2009. https://doi.org/10.1016/j.tourman.2009.02.002

[36] Sung, H.H., Classification of adventure travelers: behavior, decision making, and target markets. Journal of Travel Research, 42(4), pp. 343-356, 2004. https://doi.org/10.1177/0047287504263028

[37] Alexandris, K., Kouthouris, C., Funk, D. \& Giovani, C., Segmenting winter sport tourists by motivation: the case of recreational skiers. Journal of Hospitality Marketing \& Management, 18(5), pp. 480-499, 2009. https://doi.org/10.1080/19368620902950048

[38] Hodeck, A. \& Hovemann, G., Motivation of active sport tourists in a German highland destination - a cross-seasonal comparison. Journal of Sport \& Tourism, 30(3-4), pp. 335-348, 2016. https://doi.org/10.1080/14775085.2016.1235988

[39] Fowler, D.C., Lauderdale, M.K., Goh, B.K. \& Yuan, J., Safety concerns of international shoppers in Las Vegas. International Journal of Culture, Tourism and Hospitality Research, 6(3), pp. 238-249, 2012. https://doi.org/10.1108/17506181211246384

[40] Seabra, C., Dolnicar, S., Abrantes, J.L. \& Kastenholz, E., Heterogeneity in risk and safety perceptions of international tourists. Tourism Management, 36, pp. 502-510, 2013. https://doi.org/10.1016/j.tourman.2012.09.008

[41] Ghaderi, Z., Saboori, B. \& Khoshkam, M., Does security matter in tourism demand?. Current Issues in Tourism, 20(6), pp. 552-565, 2017. https://doi.org/10.1080/13683500.2016.1161603

[42] Flash Eurobarometer 392: Preferences of Europeans towards tourism - TNS Political \& Socia; European Commission, 2014, available at www.ec.europa.eu/commfrontoffice/ publicopinion/flash/fl_392_en.pdf (accessed 19 December 2015).

[43] George, R., Visitor perceptions of crime-safety and attitudes towards risk: the case of Table Mountain National Park, Cape Town. Tourism Management, 31(6), pp. 806-815, 2010. https://doi.org/10.1016/j.tourman.2009.08.011 
[44] Ko, Y.J., Zhang, J., Cattani, K. \& Pastore, D., Assessment of event quality in major spectator sports. Managing Service Quality: An International Journal, 21(3), pp. 304-322, 2011.

https://doi.org/10.1108/09604521111127983

[45] Soita, P.W., Measuring perceived service quality using SERVQUAL: a case study of the Uganda health and fitness sector. International Journal of Business and Social Science, 3(5), pp. 261-271, 2012.

[46] Hallmann, K., Kaplanidou, K. \& Breur, C., Event image perceptions among active and passive sport tourists at marathon races. International Journal of Sport Marketing \& Sponsorship, 12(1), pp. 37-52, 2010.

https://doi.org/10.1108/IJSMS-12-01-2010-B005

[47] Roche, S., Spake, D.F. \& Joseph, M., A model of sporting event tourism as economic development. Sport, Business and Management: An International Journal, 3(2), pp. 147-157, 2013.

https://doi.org/10.1108/20426781311325078

[48] Williams, A.P. \& Soutar, G.N., Close to the edge: critical issues for adventure tourism operators. Asia Pacific Journal of Tourism Research, 10(3), pp. 247-262, 2005. https://doi.org/10.1080/10941660500309614

[49] Shafer, S.M., Smith, H.J. \& Linder, J.C., The power of business models. Business Horizons, 48(3), pp. 199-207, 2005.

https://doi.org/10.1016/j.bushor.2004.10.014

[50] Zott, C., Amit, R. \& Massa, L., The business model: recent developments and future research. Journal of Management, 37(4), pp. 1019-1042, 2011.

https://doi.org/10.1177/0149206311406265

[51] Wirtz, B.W., Pistoia, A., Ullrich, S. \& Göttel, V., Business models: origin, development and future research perspectives. Long Range Planning, 49(1), pp. 36-54, 2016. https://doi.org/10.1016/j.lrp.2015.04.001

[52] Rayman-Bacchus, L. \& Molina A., Internet-based tourism services: business issues and trends. Futures, 33(7), pp. 589-605, 2001. https://doi.org/10.1016/S0016-3287(01)00003-9

[53] Ping, Y., A study on innovations of e-business models for Chinese tourism industry. 2010 International Forum on Information Technology and Applications, Kunming, 2010. https://doi.org/10.1109/ifita.2010.268

[54] Kabir, M.A., Jahan, K., Adnan, Md. N. \& Khan, N., Business model of e-tourism for developing countries. International Journal of Computer and Information Technology, 3(1), pp. 30-34, 2012.

[55] Runfola, A., Rosati, M. \& Guercini, S., New business models in online hotel distribution: emerging private sales versus leading IDS. Service Business, 7(2), pp. 183-205, 2013. https://doi.org/10.1007/s11628-012-0150-1

[56] Mosleh, A., Nosratabadi, S. \& Bahrami, P., Recognizing the business models types in tourism agencies: utilizing the cluster analysis. International Business Research, 8(2), pp. 173-180, 2015.

https://doi.org/10.5539/ibr.v8n2p173 
[57] Perić, M. \& Wise, N., Understanding the delivery of experience: conceptualising business models and sports tourism, assessing two case studies in Istria, Croatia. Local Economy, 30(8), pp. 1000-1016, 2015. https://doi.org/10.1177/0269094215604131

[58] Johnson, M.W., Christensen, C.M. \& Kagermann, H., Reinventing your business model. Harvard Business Review, 86(12), pp. 50-59, 2008.

[59] Coles, T., Warren, N., Borden, D.S. \& Dinan, C., Business models among SMTEs: identifying attitudes to environmental costs and their implications for sustainable tourism. Journal of Sustainable Tourism, 25(4), 2017. https://doi.org/10.1080/09669582.2016.1221414

[60] Perić, M., Wise, N. \& Dragičević, D., Suggesting a service research agenda in sport tourism: working experience(s) into business models. Sport, Business and Management: An International Journal, 7(1), pp. 58-76, 2017. https://doi.org/10.1108/SBM-09-2015-0031

[61] Stubbs, W. \& Cocklin, C., Conceptualizing a "Sustainability Business Model". Organization \& Environment, 21(2), pp. 103-127, 2008. https://doi.org/10.1177/1086026608318042

[62] Schaltegger, S., Hansen, E.G. \& Lüdeke-Freund, F., Business models for sustainability: origins, present research, and future avenues. Organization \& Environment, 29(1), pp. 3-10, 2016. https://doi.org/10.1177/1086026615599806

[63] Hoque, F., The alignment effect. Upper Saddle River, New York: Prentice Hall, 2002.

[64] Nair, S., Paulose, H., Palacios, M. \& Tafur, J., Service orientation: effectuating business model innovation. The Service Industries Journal, 33(9-10), pp. 958-975, 2013. https://doi.org/10.1080/02642069.2013.746670

[65] Morris, T. \& Rogers, H., Measuring motives for physical activity. Sport and Chance of Life: Proceedings of 2004 International Sport Science Congress, pp. 242-250, 2004. 